\title{
A ORIGEM DO ACAMAMENTO MAGMÁTICO NO GRANITO PEDRA BRANCA, MACIÇO DA PEDRA BRANCA, RIO DE JANEIRO, BRASIL.
}

\author{
THE ORIGIN OF THE MAGMATIC BEDDING IN THE PEDRA BRANCA GRANITE, PEDRA \\ BRANCA MASSIF, RIO DE JANEIRO, BRAZIL.
}

\author{
Rubem PORTO JÚNIOR ${ }^{1}$, Lucas Ramos TESSER ${ }^{1}$, Beatriz Paschoal DUARTE ${ }^{2}$ \\ ${ }^{1}$ Universidade Federal Rural do Rio de Janeiro. Emails: rubempjr@ gmail.com; ltesser.ufrrj@ gmail.com \\ ${ }^{2}$ Universidade do Estado do Rio de Janeiro. E-mail: biapasch@gmail.com

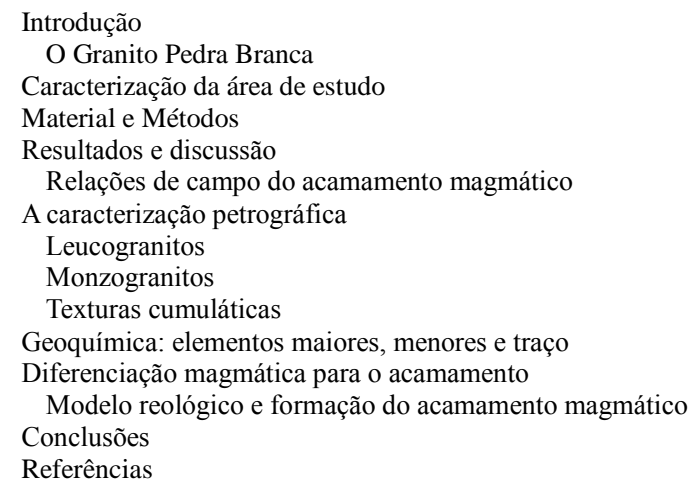

RESUMO - O Granito Pedra Branca está localizado na região oeste da cidade do Rio de Janeiro e corresponde a um dos corpos intrusivos mais importantes associados ao estágio tardi a pós- tectônico no segmento central do Orógeno Ribeira. Em uma de suas faciologias, excepcionais estruturas de acamamento magmático são formadas pela intercalação de bandas de rochas de composição monzogranítica e leucogranítica. A fim de compreender os processos físico-químicos e a forma de ocorrência dessas estruturas, foram realizados estudos de campo, petrográficos e litogeoquímicos. A análise dos resultados mostrou que o acamamento magmático é co-genético com as demais litologias encontradas no Granito Pedra Branca e sua forma de ocorrência é restrita às zonas de borda da intrusão. A sua diferenciação magmática foi atribuída à ascensão do magma próximo à borda dos condutos, favorecendo a cristalização "in situ" e, posteriormente, com cerca de $72 \%$ de material cristalizado, o crystal mush foi submetido ao processo de filter pressing favorecendo a migração do líquido residual para regiões de baixos gradientes de pressão, gerando uma estrutura de acamamento magmático.

Palavras-chave: Granito Pedra Branca; Acamamento Magmático; Dinâmica de Magmas Graníticos.

\begin{abstract}
Pedra Branca Granite occurs on the western region of Rio de Janeiro city and corresponds to one of the most important intrusive bodies associated with the late- to post-tectonic stage of the Ribeira Orogen. Exceptional magmatic foliation structures, given by the interlayering ot monzogranitic and leucogranitic bands were mapped. To understand the physical and chemical processes and the form of occurrence of these structures, field, petrographic and lithogeochemical studies were carried out. Results show that the magmatic layering is co-genetic with other facies found in Pedra Branca Granite and that its form of occurrence is restricted to the intrusion borders. Its genesis is attributed to magmatic differentiation, as follows: with the ascension of the magma, crystallization "in situ" was favored near the edge of the conduits; with about $72 \%$ of crystallized material, the "crystal mush" was compressed by "filter pressing" process, favoring migration of intercumulatic a low pressure gradient path, generating a magmatic layering structure.
\end{abstract}

Keywords: Pedra Branca's Intrusion; Magmatic Layering; Granitic Magma Dynamics.

\section{INTRODUÇÃO}

Processos combinados de cristalização e mecanismos físicos de fracionamento cristallíquido são há muito tempo tema de debate na área da petrologia de rochas graníticas. A compreensão de processos de fluxo magmático é de grande interesse científico, tendo em vista que é essencial entender o comportamento fluidodinâmico de magmas para melhor caracterizar a forma de ascensão e posicionamento de plútons graníticos (Tait \& Jaupart, 1990). Estruturas de fluxo magmático como alinhamento de megacristais (foliação críptica), deformação de enclaves e bandamento magmático vêm sendo utilizadas para definir e entender a evolução magmática e alojamento de plútons graníticos em orógenos colisionais (Weinberg et al., 2001). Estratificação modal como encontrada em intrusões máficas acamadadas também ocorre em intrusões ácidas, porém, em geral, com expressão menos desenvolvida e origem ainda muito controversa. Contudo, exemplos de diversos plútons graníticos já foram descritos (Pons et al., 2006), apresentando características muito semelhantes a intrusões gabroicas, como em Skaergaard (Mcbirney, 1975a).

Dentro do Complexo Pedra Branca (CPB) localizado no segmento central da Faixa 
Ribeira, foram mapeadas estruturas de acamamento magmático que, quando individualizadas, caracterizam a fácies hololeucocrática do Granito Pedra Branca (Porto Jr., 1993). Excepcionais estruturas de intercalação em camadas de composições distintas e apresentando texturas cumuláticas nesse granito, fornecem um importante laboratório para compreender a dinâmica de magmas muito viscosos, portanto, dentro do campo dos fluidos não newtonianos, que são de complexa modelagem geológica.

Neste estudo são descritas estruturas que indicam estabilidade próxima ao mínimo granítico (eutético) para os leucogranitos que compõem o acamamento magmático, bem como, constata-se a influência do processo de compactação do "crystal mush", por "filter pressing” (Mckenzie, 1987), relação refletida principalmente no empobrecimento de elementos de terras raras leves na evolução magmática da faciologia envolvida. Será proposto ainda um modelo reológico de evolução para o Granito Pedra Branca e a estrutura de acamamento magmático, levandose principalmente em consideração a evolução do estado físico do magma e os respectivos mecanismos de diferenciação magmática vigentes.

\section{O Granito Pedra Branca}

O Granito Pedra Branca está inserido dentro do contexto geológico da evolução do Segmento Central da Faixa Ribeira, equivalente, em parte, ao Cinturão Móvel Ribeira (Almeida et al., 1973) ou a porção central da Província Mantiqueira (Hasui \& Oliveira, 1984).

A Faixa Móvel Ribeira, de idade neoproterozoica a eopaleozoica, compreende um complexo sistema de dobramentos e empurrões, gerados junto à borda sul-sudeste do Cráton do São Francisco, e mostra uma extensão de cerca de $1.400 \mathrm{~km}$ ao longo da costa atlântica brasileira. Pesquisas sistemáticas nesta região têm demonstrado que a estruturação geral deste grande compartimento tectônico se encontra intimamente relacionada a uma etapa inicial de encurtamento crustal com vergência para NNW, acompanhada de grandes dobramentos em escala regional. Posteriormente, uma nova compressão E-W gerou zonas de cisalhamento transpressionais subverticais, de orientação NE-SW e cinemática dextral (Heilbron et al., 1995a).

Heilbron et al., (1995b) definem, para o segmento central da Faixa Ribeira, dois diferentes terrenos: a) Terreno Ocidental, referente à margem retrabalhada do Cráton do São Francisco, sendo compreendido pelas unidades litotectônicas Andrelândia, Juiz de Fora e Paraíba do Sul e; b) Terreno Oriental, composto pelo Domínio Costeiro (ou microplaca Serra do Mar), com blocos cratônicos e microplacas, possivelmente associadas, Complexo Rio Negro (Tupinambá et al., 1998) composto por granitoides précolisionais, gerados em um ambiente de um arco magmático com idade entre 630-600 Ma, e o Domínio Tectônico Cabo Frio (Schmitt, 2001) que representa a última colagem no sistema orogênico entre 500-490 Ma.

Inserido tectonicamente no Domínio Costeiro, a origem do Granito Pedra Branca foi proposta por diversos autores, dos quais podem ser destacados os trabalhos de Heilbron \& Machado (2003) e por Porto Jr. (2004). Segundo os autores, a evolução cronológica do granito e de suas rochas encaixantes, pode ser sumarizada da seguinte maneira: 1) gnaisses paraderivados relacionados a uma bacia de margem passiva neoproterozoica, de idade absoluta não estabelecida; 2) gnaisses ortoderivados pré- a sin-colisionais, de idades $792 \mathrm{Ma}$ e $578 \mathrm{Ma}$, respectivamente; 3) granitoides dioríticos a granodioríticos tardi- a pós-colisionais (tardi- a pós-D3), com idade de $520 \mathrm{Ma}$; 4) o objeto de estudo deste artigo, Granito Pedra Branca, pós-tectônico (pós-D3), com idade de $513 \mathrm{Ma}$; 5) o último evento magmático, que corresponde ao Granito Favela/Andorinha, francamente pós-colisional, com idade de $480 \mathrm{Ma}$.

Com cerca de $150 \mathrm{Km}^{2}$ de área, o Granito Pedra Branca é levemente alongado na direção preferencial dos grandes lineamentos regionais (NE-SW) conferido pelas rochas encaixantes (Figura 1). Marcado por forte anisotropia, o Granito Pedra Branca possui estruturas de fluxo magmático e foliação dada pelo alinhamento de megacristais de feldspato potássico (Penha, 1984; Penha \& Wiedemann, 1984). Próximo à borda da intrusão, e subparalelo à mesma, o aspecto de rocha foliada, bem como a presença de enclaves deformados, é conspícuo, sendo interpretado 
como resultado de componentes de tensões diapíricas que ocorreram durante a ascensão do magma em conjunto com forças tectônicas póscolisionais (pós-D 3 ) (Porto Jr., 2004). Segundo Porto Jr (2004), em escala de detalhe, o Granito Pedra Branca (pós-D3) pode ser subdividido em quatro fácies de acordo com suas características petrográficas e estruturais: a) média-homogênea, dominante em termos de área; b) bandada; c) pegmatítica; d) hololeucocrática, sendo esta última caracterizada por estruturas de bandamento magmático.
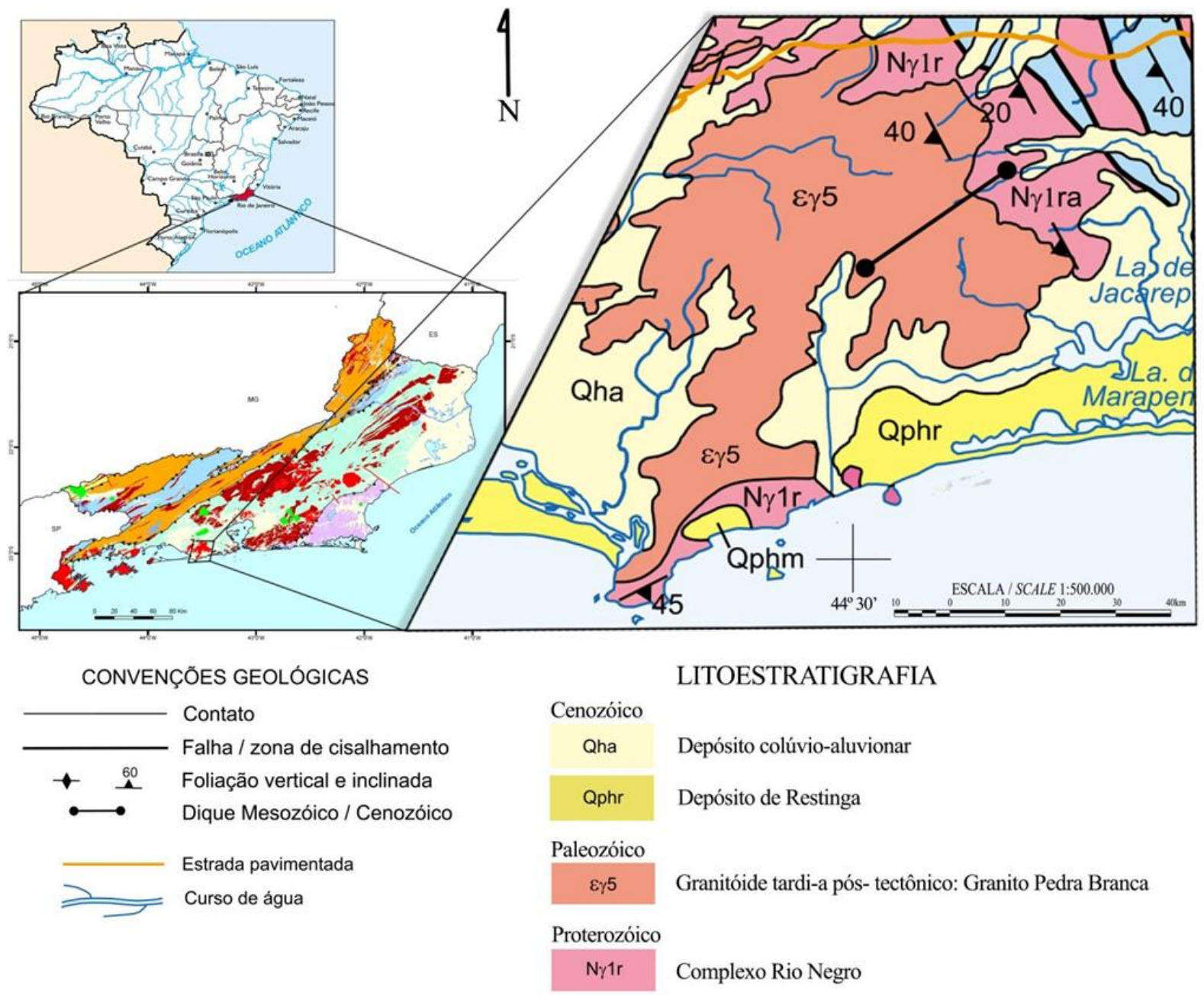

Figura 1 - Mapa geológico do Granito Pedra Branca. Modificado do mapa geológico com Estado do Rio de Janeiro (Silva et al., 2000). Detalhe para a área de exposição e contatos referente ao Granito Pedra Branca.

A fácies média-homogênea (Porto $\mathrm{Jr} \&$ Valente, 1988) tem como característica a presença de megacristais de microclina pertítica, com granulação média de até $2 \mathrm{~cm}$, podendo alcançar até $4 \mathrm{~cm}$, envolvida por uma matriz de granulação média, rica em quartzo, plagioclásio e microclima e texturalmente muito homogênea.

A fácies bandada (Porto Jr, 1993) é a segunda em área de ocorrência, mas com difícil individualização em mapas ou perfis em escalas menores que 1:10000. Isso acontece porque sua individualização se dá em função do crescimento dos megacristais de microclina para granulações que variam em média de 5 até $7 \mathrm{~cm}$. Em função do hábito colunar destes grãos a rocha assume um bandamento característico principalmente quando observado em grandes exposições.

O bandamento é ainda realçado pela coexistência de "filetes" de biotita, alinhados segundo a foliação de fluxo desenvolvida pelos megacristais de microclina. Estes "filetes" de biotita podem tratar-se de enclaves microgranulares máficos, ou de enclaves xenolíticos muito assimilados, ou ainda de "schlieren" de biotita, interpretados por Porto Jr (1994) como fruto de uma possível segregação e acumulação em função do fluxo magmático.

A fácies pegmatítica (Porto Jr \& Valente, 1988) só apresenta possibilidade de individualização em perfis de pedreiras. Ocorre 
sob forma de diques e/ou bolsões pegmatíticos posicionados de forma sub concordante às estruturas das rochas encaixantes. São compostos por cerca de $75 \%$ de cristais de microclina pertítica, possuindo granulação média de $6 \mathrm{~cm}$, podendo ocorrer grãos de 12 $\mathrm{cm}$. Quando sob forma de diques, os grãos de microclina podem apresentar-se alinhados segundo uma direção preferencial de fluxo, porém quando exposto sob forma de bolsões ou veios, nenhum alinhamento é observado.

A fácies hololeucocrática (Porto Jr., 1993) é, dentre todas as fácies do Granito Pedra Branca, a mais restrita em área e de mais difícil representação em mapa, já que se limita, em forma de ocorrência, a bandas interestratificadas homogêneas e contrastantes em relação à fácies média-homogênea, que em todos os casos observados lhe serve de rocha hospedeira.

\section{MATERIAIS E MÉTODOS}

O estudo aqui apresentado está baseado em observações de campo, petrografia e geoquímica para as rochas que representam a fácies hololeucocrática. $\mathrm{Na}$ etapa de campo os dados foram coletados em centenas de afloramentos de rocha, principalmente aqueles localizados em frentes de pedreiras que ocorrem na área do Granito Pedra Branca.

O estudo ao microscópio foi realizado a partir do exame de 30 lâminas delgadas de rocha estudadas sob microscópio de luz transmitida Olimpus BX-40 do DG/IA/UFRRJ, onde também foram realizadas as fotomicrografias. Dez amostras foram preparadas para análise geoquímica, sendo que 9 representam amostras do leucogranito e 1 representa o monzogranito. Para todas as amostras foram obtidos elementos maiores, menores e traço, incluindo ETR, todas realizadas nos laboratórios da ACTLABS (Actvation Laboratories), no Canadá. As amostras analisadas no laboratório de geoquímica foram submetidas às seguintes técnicas de detecção: a) elementos maiores, Ba, Sr, Y, Zr, Sc, $\mathrm{Be}$ e $\mathrm{V}$ por ICP/AES (Inductively Coupled Plasma - Atomic Emission Spectrometry); e b) todos os demais elementos traço incluindo as terras raras por ICP/MS (Inductively Coupled Plasma - Mass Spectrometry).

No primeiro caso, ICP/AES, a amostra é dissolvida pela utilização de ácidos puros ou misturada por fusões, com emprego de agentes fundentes. A solução obtida é então introduzida em um plasma excitado a cerca de $8000^{\circ} \mathrm{K}$. Cada elemento produz um espectro característico cuja intensidade das linhas espectrais é proporcional à quantidade do elemento presente na fusão.

No segundo caso, ICP/MS, agrega-se o material em chamas pela técnica padrão do ICP a um espectrômetro de massa para medir a massa do elemento.

\section{RESULTADOS E DISCUSSÃO}

\section{Relações de Campo do Acamamento Magmático}

No caso estudado, as estruturas de acamamento magmático são definidas e delineadas na interface entre as fácies hololeucocrática (leucogranito) e médiahomogênea (monzogranito) no Granito Pedra Branca (Porto Jr., 1993).

Geograficamente, as estruturas de acamamento magmático são intimamente relacionadas a zonas de contato do Granito Pedra Branca com as rochas encaixantes, principalmente nas porções norte e sul do CPB. O leucogranito, disposto em bandas de coloração branca, compostas essencialmente por microclina, plagioclásio e quartzo, com baixas concentrações ou até mesmo ausência de minerais máficos, compõe a fácies hololeucocrática. Intercaladas a esta fácies ocorrem monzogranitos correspondentes à fácies média-homogênea, que formam as mais extensas bandas, gerando o aspecto acamadado que contrasta com os leucogranitos (Figura 2).

Os monzogranitos são compostos essencialmente por microclina, plagioclásio, quartzo e biotita, com allanita, zircão, apatita e minerais opacos como minerais acessórios que ocorrem em pequeno volume. As bandas possuem espessuras variadas, desde finas (5 $\mathrm{cm}$ ) até mais espessas (até $60 \mathrm{~cm}$ ), com comprimento que pode ultrapassar dezenas de metros, mantendo-se sempre com grande homogeneidade vertical e lateral (Figura 3).

A anisotropia dada pela estrutura de fluxo é evidente pela constante intercalação de camadas esbranquiçadas de leucogranitos com camadas cinza de monzogranitos e pelo padrão orientado dos minerais por fluxo. 


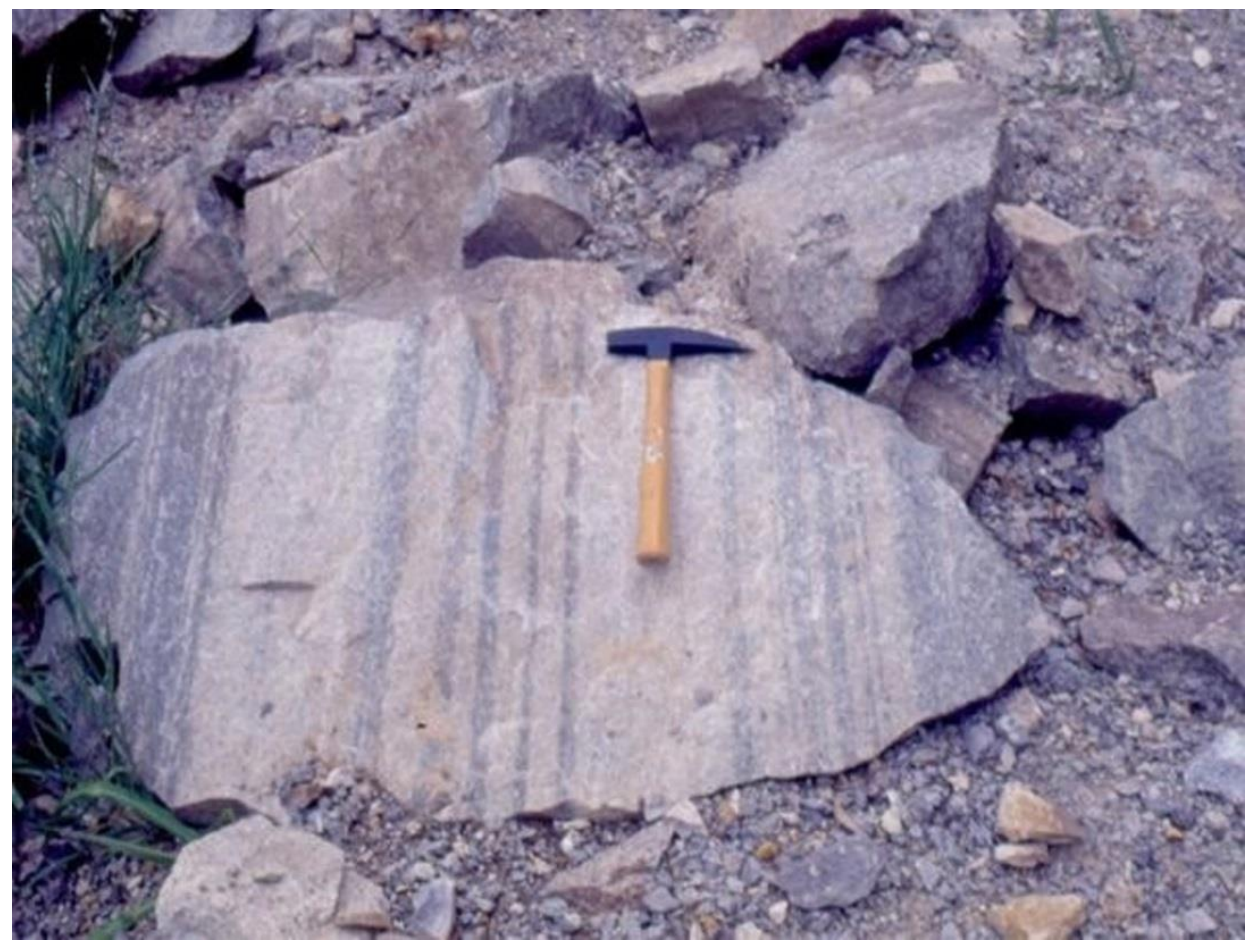

Figura 2 - Padrão estrutural do acamamento magmático. As camadas esbranquiçadas compõem os leucogranitos, intercalados aos monzogranitos de coloração cinza/rosa. Procedência: Pedreira EMASA, Jabour, Bangu, Rio de Janeiro.

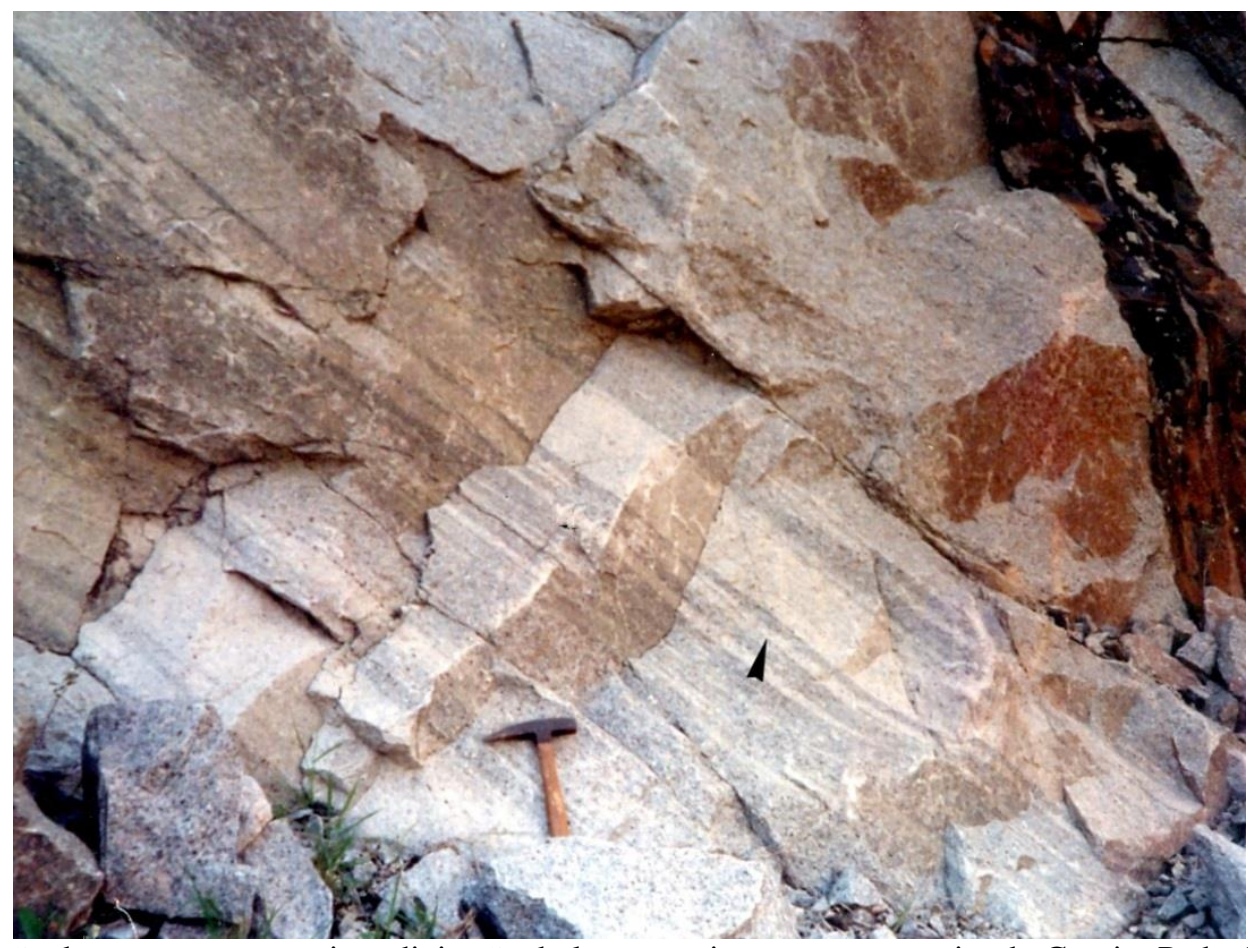

Figura 3 - Padrão do acamamento e a interdigitação do leucogranito no monzogranito do Granito Pedra Branca. Notar a homogeneidade de espessuras entre as camadas. Procedência: Pedreira EMASA, Jabour, Bangu, Rio de Janeiro.

A geometria extremamente horizontalizada e homogênea das bandas, associado à ausência de bordas resfriadas nos contatos entre as camadas adjacentes, é interpretada como feição resultante do baixo contraste de viscosidade e temperatura existente no momento da formação das estruturas que compõem o bandamento.

A ausência de deformação das bandas é forte indicativo do caráter sin-magmático das camadas, sendo a origem do acamamento exclusivamente atribuída a processos magmáticos (não-tectônicos) que, possivelmente ocorreram nos estágios finais da cristalização do Granito Pedra Branca, dado as características petrográficas e mineralógicas do leucogranito, que apontam para um intervalo de cristalização no mínimo granítico. 


\section{A CARACTERIZAÇÃO PETROGRÁFICA}

\section{Leucogranitos}

Os leucogranitos são caracterizados por uma composição mineralógica extremamente equilibrada e característica dentre as litologias que compreendem o Granito Pedra Branca.

Como pode ser observado na figura 4 , essas rochas são constituídas essencialmente de microclina, plagioclásio e quartzo, com apatita e zircão em volume muito reduzido $(<0,5 \% \mathrm{em}$ volume) e biotita e minerais opacos ausentes ou em quantidades muito restritas, além de produtos secundários de alteração.

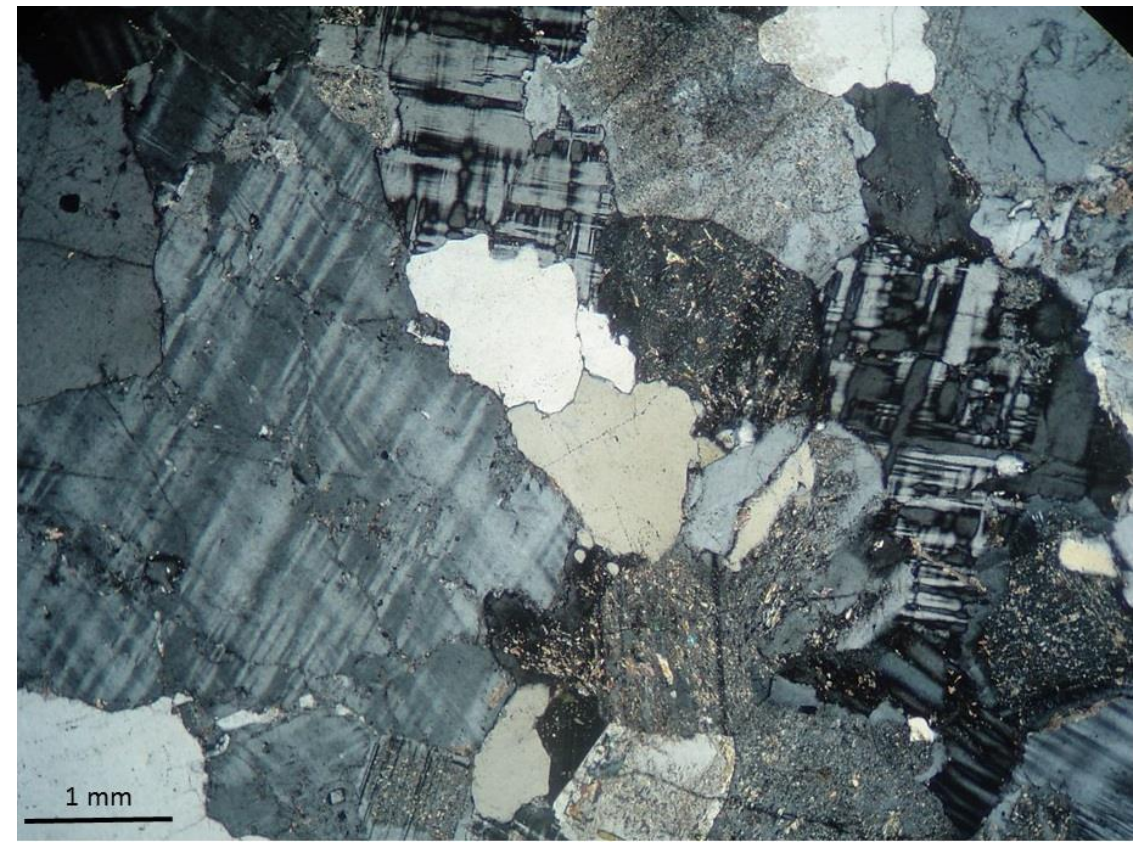

Figura 4 - Aspecto geral do leucogranito. Observar a baixa concentração de minerais máficos/acessórios e altas concentrações de feldspatos.

A microclina tem granulação média ( 3 a 5 $\mathrm{mm})$, sua forma varia de anédrica a subédrica, em grãos de hábito granular a quadrático. É comum de ocorrência ainda em grãos tabulares a colunares, e quando isso ocorre, os grãos de microclina apresentam granulação mais grossa, podendo atingir até $7 \mathrm{~mm}$.
As inclusões são essencialmente de quartzo de formas arredondadas e de gotas, além de plagioclásio fortemente saussuritizado. Em alguns grãos poiquiliticos de microclina é observado padrão de zoneamento das inclusões de quartzo, demostrando diferentes fases de crescimento para esse mineral (Figura 5).

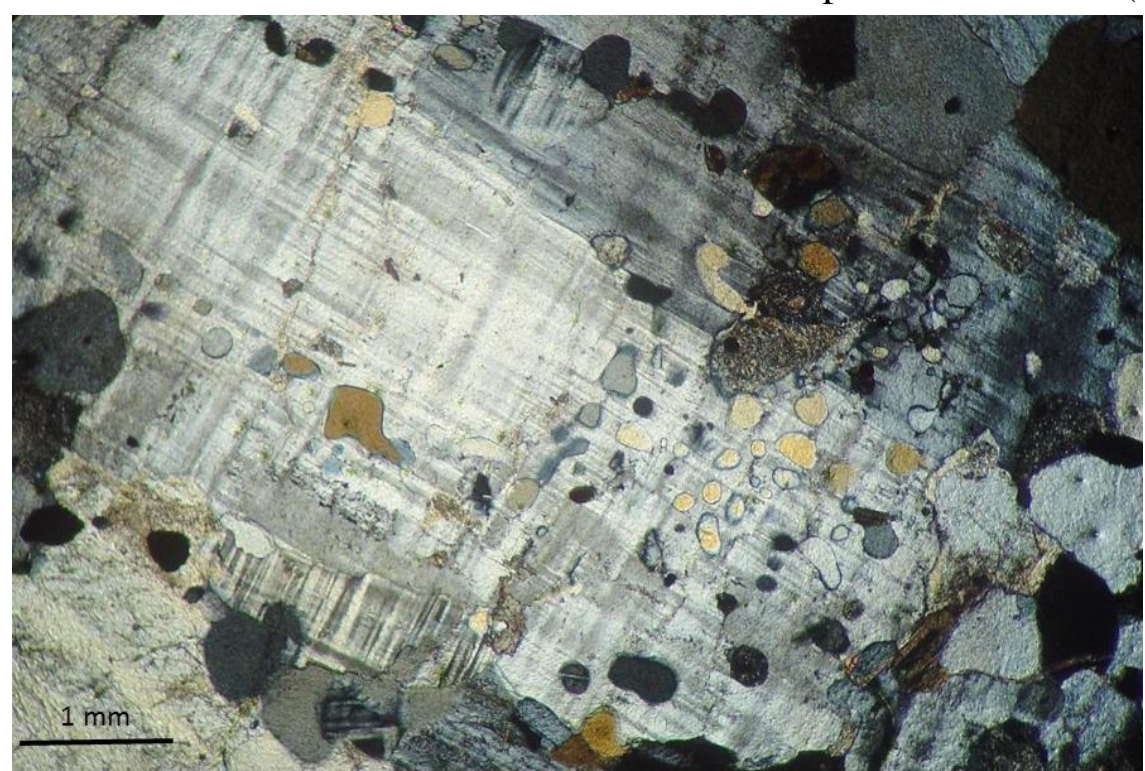

Figura 5 - Padrão de inclusões de quartzo em megacristais de microclina de até $7 \mathrm{~mm}$ nos leucogranitos. Observar a geometria elipsoidal e em gotas desenvolvida pelas inclusões. 


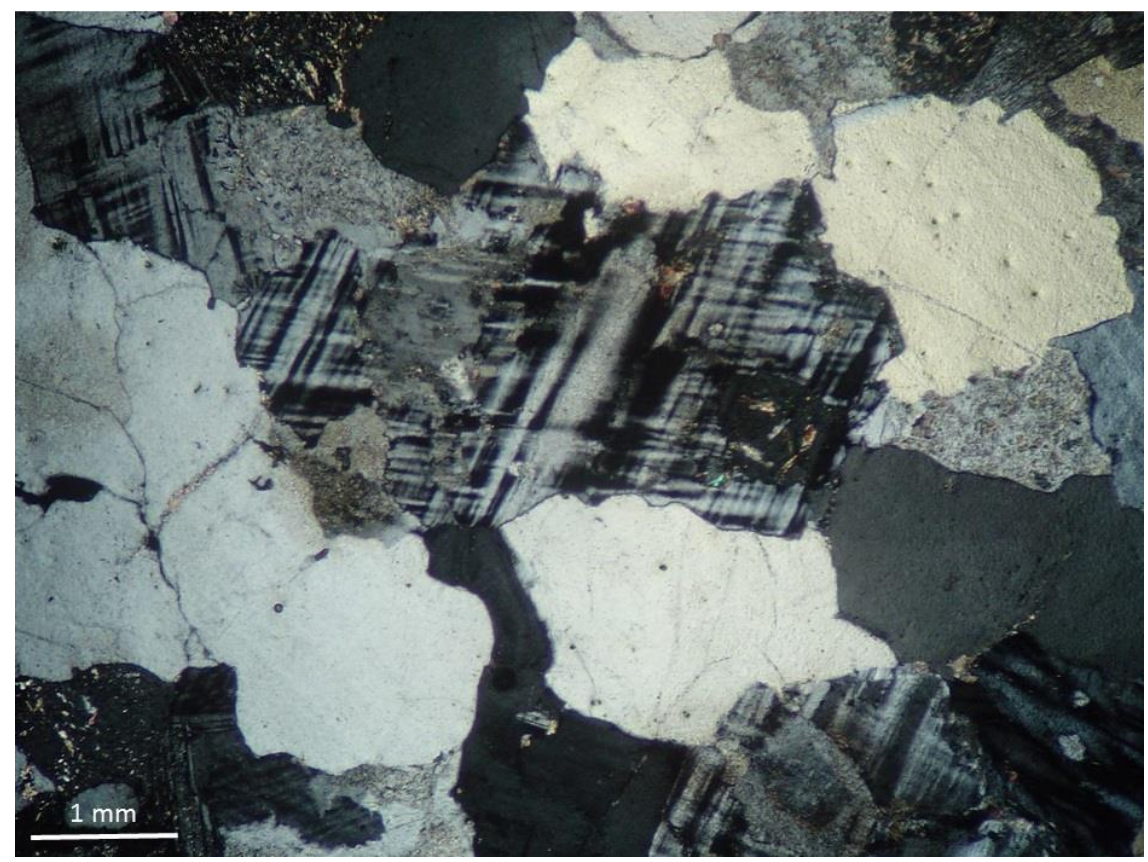

Figura 6 - Grãos anédricos de quartzo em contato do tipo "embainhamento" com megacristais de microclina nos leucogranitos.

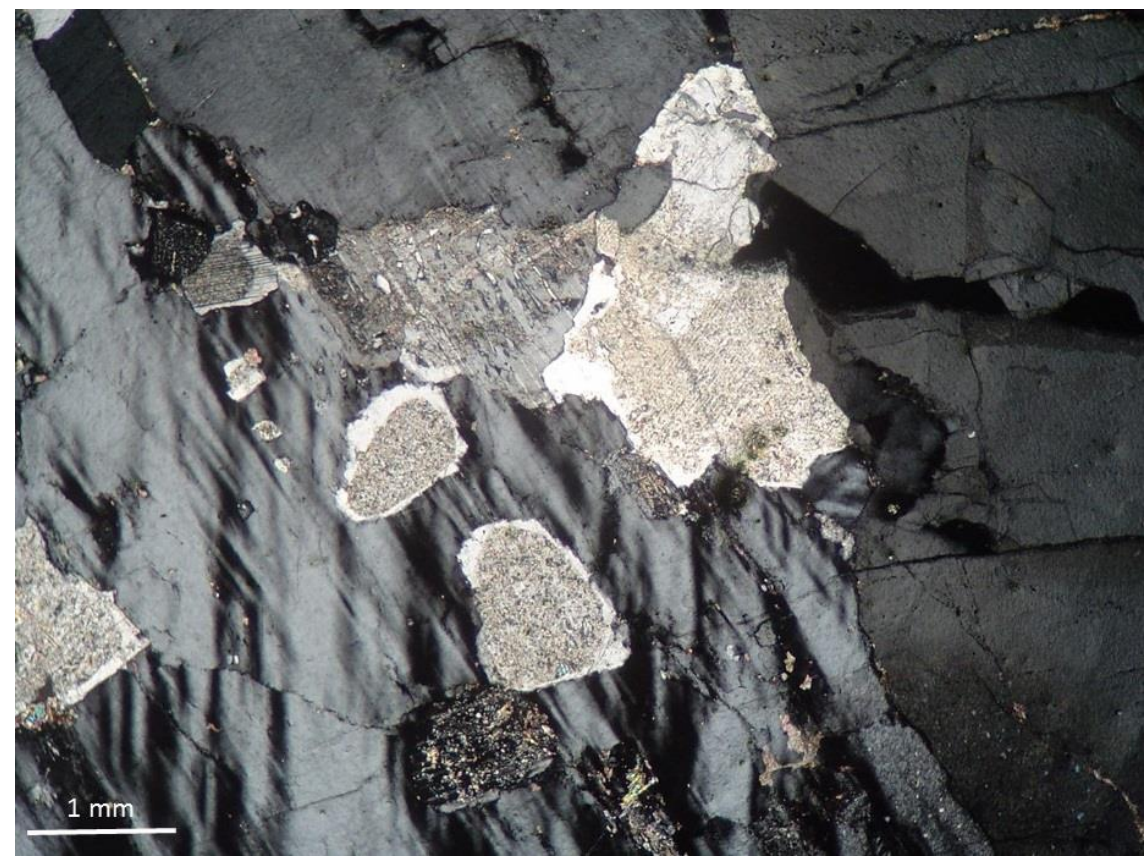

Figura 7 - Plagioclásio de primeira geração com sobrecrescimento sintaxial de composição albítica, incluso em megacristal de microclina nos leucogranitos.

Os contornos externos dos grãos de saussuritizados com bordas de microclina quase sempre são corroídos, sobrecrescimento sintaxial e, em geral, estão eventualmente formando contornos do tipo inclusos em megacristais de microclina; 2) os côncavo-convexo com grãos anédricos de de segunda geração são saussuritizados, porém quartzo (Figura 6). O plagioclásio é anédrico a não mostram bordas de sobrecrescimento; e 3) subédrico, com hábito variando de granular a a terceira geração de grãos de plagioclásio tabular, com tamanho no intervalo de $1 \mathrm{a} 4 \mathrm{~mm}$, apresenta-se como grãos sobrecrescidos, de além disso, os grãos apresentam forte grau de composição provavelmente mais sódica saussuritização.

Foram caracterizadas três gerações de plagioclásio: 1) os de primeira geração são aqueles que se mostram totalmente (albítica) em relação aos da primeira geração (Figura 7).

O quartzo, na matriz, é anédrico com grãos entre 2 e $3 \mathrm{~mm}$. Seu crescimento é tardio em 
relação ao plagioclásio e concomitante ao da microclina, com quem mostra contatos irregulares. Finas inclusões de quartzo com forma anédrica em microclina são comuns. Inclusões de quartzo em microclina são comuns.

\section{Monzogranitos}

As rochas de composição monzogranítica correspondem àquelas caracterizadas como pertencentes à fácies média-homogênea. Compreendem monzogranitos de cor cinza clara e textura porfirítica com megacristais de $\mathrm{K}$-feldspato em matriz equigranular, hipidiomórfica grossa, composta por microclina, plagioclásio, quartzo, biotita, minerais opacos, allanita, apatita, zircão e produtos de alteração secundária (Figura 8).

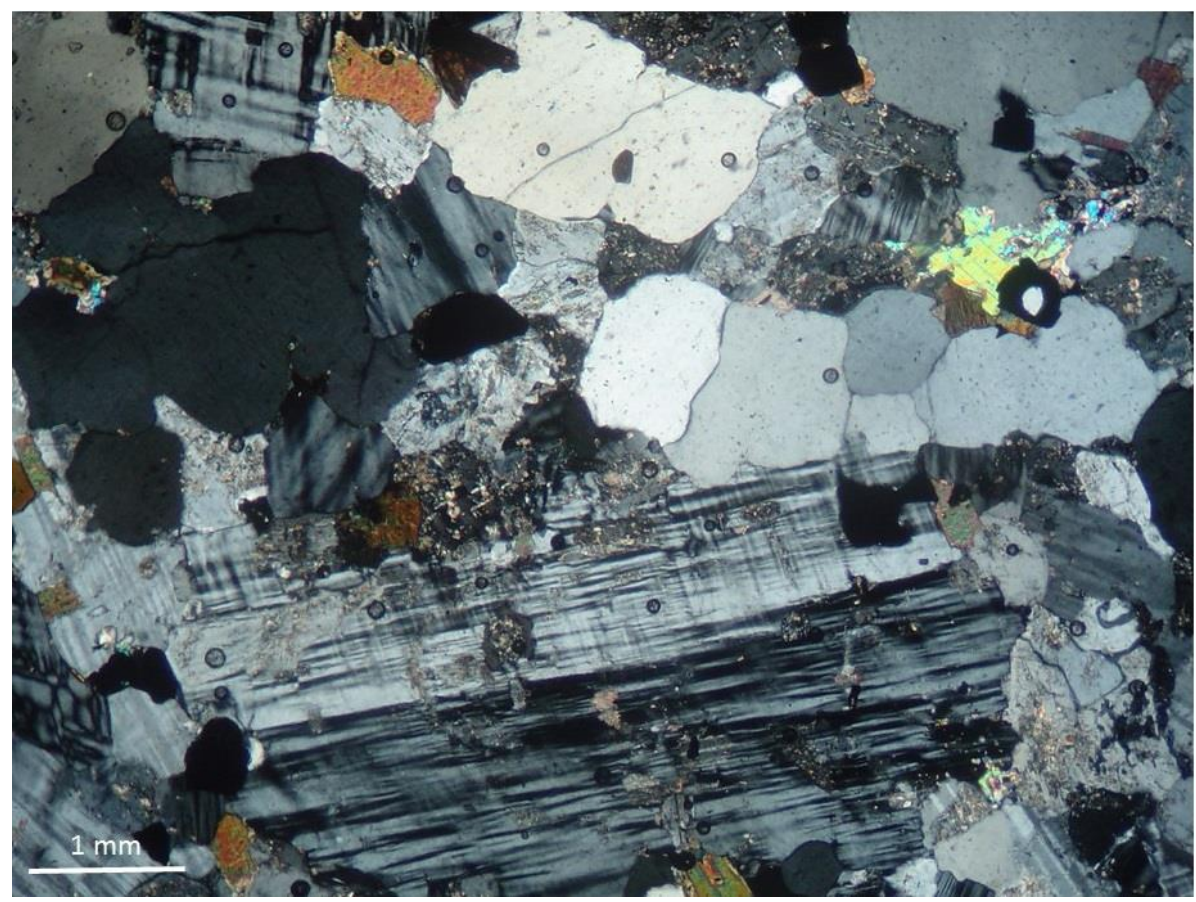

Figura 8 - Monzogranito porfirítico com megacristais de microclina de até $20 \mathrm{~mm}$.

A microclina, dominante em volume, apresenta granulação que varia de média (na matriz) a grossa, correspondendo aos megacristais, no intervalo respectivamente, de 4,0 $\mathrm{mm}$ a $20 \mathrm{~mm}$. O hábito pode variar de quadrático a colunar e os grãos são frequentemente geminados por "Tartan" e por Carlsbad. São grãos subédricos, micropertíticos, poiquiliticos, com inclusões de todas as fases minerais precoces, o que sugere caráter tardio do crescimento desse mineral ou sua formação por "sinneusys" (Vance, 1969).

As inclusões possuem ampla distribuição e formas variadas, frequentemente compostas de quartzo de forma de gotas e plagioclásio com forma colunar. É comum a presença de textura mirmequítica nos contatos com grãos de plagioclásio.

É corriqueiro contatos do tipo "embayment" que mostram processos de reação entre $o$ quartzo na matriz com grãos de microclina.

O plagioclásio apresenta volume menor que o da microclina. Seus grãos variam de anédricos a subédricos com hábito variando de granular a quadrático.

São grãos médios que variam de 2 a $4 \mathrm{~mm}$. Apresentam-se sempre muito alterados por processos secundários, podendo levar à formação de finos grãos de muscovita.

O quartzo é abundante, ocorrendo em grãos anédricos intergranulares. Sua granulação varia de fina a grossa, com grãos no intervalo de 0,5 $\mathrm{mm}$ a $20 \mathrm{~mm}$.

A biotita está presente em pequeno volume $(3,5 \%)$, ocorrendo dispersa na matriz da rocha em grãos subédricos de hábito tabular e granulação média (1 a $2 \mathrm{~mm})$. Está frequentemente cloritizada a partir de seus planos de clivagens.

Minerais acessórios como a allanita, apatita e zircão ocorrem de forma dispersa como inclusões em grãos de microclina e plagioclásio (Figura 9).

A Ilmenita e magnetita ocorrem sempre em associação em um único cristal, sob forma de exsolução de ilmenita em magnetita. A hematita ocorre em grãos individuais subédricos a anédricos e de granulação média 
(1 a $2 \mathrm{~mm}$ ). A pirita é rara, ocorrendo em grãos de granulação fina $(<1 \mathrm{~mm})$. De acordo com Porto Jr. (2004c), a presença de allanita está sempre associada às regiões de contato do Granito Pedra Branca com os ortognaisses encaixantes.

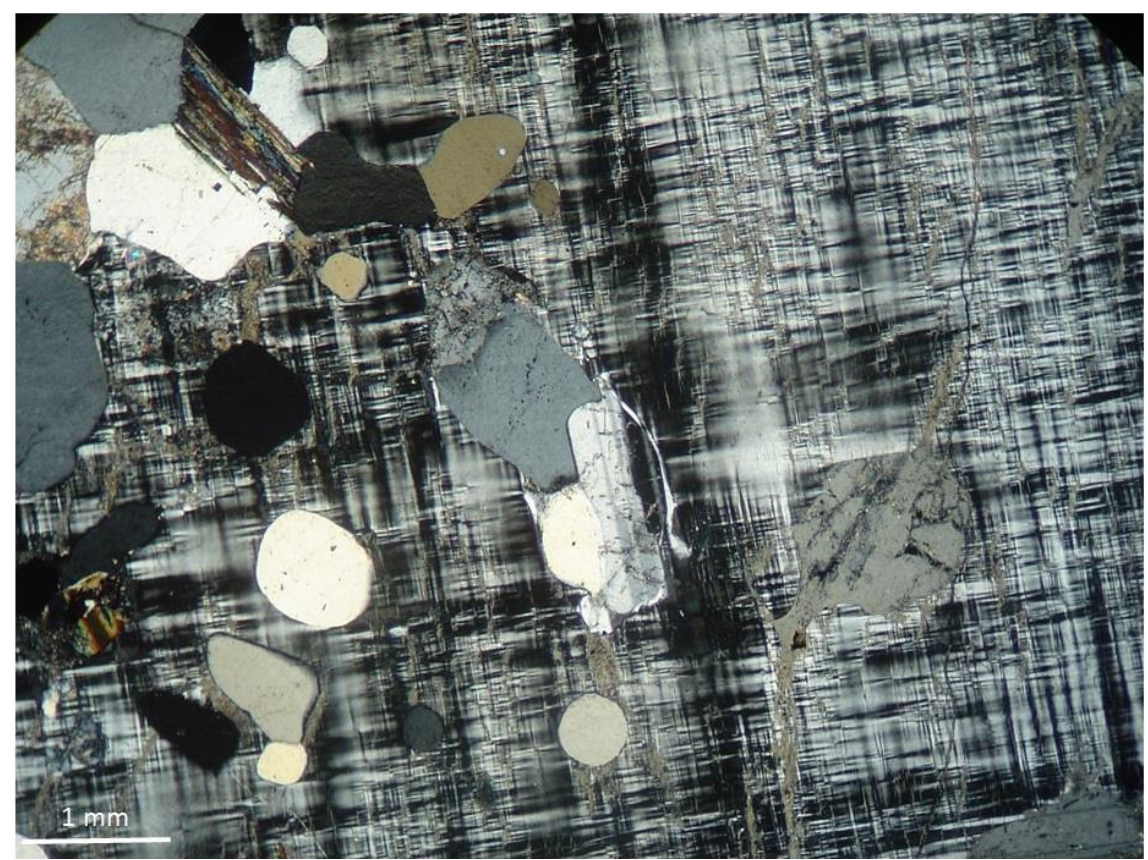

Figura 9 - Detalhe dos monzogranitos sob nicóis cruzados, mostrando inclusões de fases precoces em megacristal de microclina.

\section{Texturas Cumuláticas}

A heterogeneidade mineralógica caracteriza de uma maneira peculiar o acamamento modal observado no Granito Pedra Branca, em analogia com aqueles descritos em intrusões máficas acamadadas. O desaparecimento ou cristalização muito limitada de fases opacas e minerais acessórios, associada à cristalização de feldspatos e quartzo, são fortes indícios que o magma que gerou o acamamento magmático caminhava para composições muito próximas do mínimo granítico.

Em termos de texturas, o arcabouço de grãos de microclina (fenocristais) apresenta-se sempre em contatos mútuos, interpretado como de origem cumulática, devendo ser assumido que sua cristalização não se deu "in situ”".

Os grãos de microclina são interespaçados por grãos de quartzo e plagioclásio, que provavelmente se cristalizaram "in situ", a partir de um líquido magmático intercumulático. Ainda no estágio final da cristalização, o líquido intercumulático, em vez de formar células isoladas, manteve os canais de difusão ou de migração abertos para o reservatório de líquido magmático principal, formando "filmes", permitindo assim o reequilíbrio químico dos cristais sobrejacentes.
Consequentemente, a cristalização do liquido intercumulático pode ter agido de forma a aumentar a granulação dos cristais cumuláticos existentes, formando crescimentos secundários (Wager et al., 1960).

Sobrecrescimentos são texturas comuns a grãos de plagioclásio de primeira geração nos leucogranitos (Figura 7), demonstrando que o líquido intercumulático, muito enriquecido em voláteis, pode ter agido de forma a desestabilizar a composição química dos feldspatos cumuláticos. $\mathrm{O}$ zoneamento em padrão circular esboçado na forma de inclusões de quartzo em microclina (figura 5) está diretamente ligado aos fatores cinéticos que controlam o crescimento do mineral. As explicações para a gênese de tal feição são variadas, com o quartzo podendo representar: 1) restos de grãos maiores, cujas formas implicam na aceitação de processos de fusão parcial, processo comum na gênese de migmatitos; 2) mineral primário "liquidus", posteriormente englobado como inclusões pelos grãos de microclina; e 3) produto de coprecipitação de quartzo e microclina (Porto Jr., 2002).

A observação de contatos do tipo "embayment" entre microclina e quartzo 
demonstra que houve a atuação de processos de reação cristal-líquido, provavelmente devido a diferenças composicionais entre o líquido intercumulático residual, que se cristalizou sob forma de quartzo e plagioclásio, e a microclina de origem cumulática.

Tabela 1 - Elementos maiores, menores (em \% em peso) e traço (em PPM) analisados para a fácies hololeucocrática e média-homogênea do Granito Pedra Branca.

\begin{tabular}{|c|c|c|c|c|c|c|c|c|c|c|}
\hline Amostra & PBG 2 & RG-05 & PIT-08 & PJT-10C & PJT-5A & PST-5A & PJT-10A & PIT-03E & PJT-8 & PJT-12 F \\
\hline & \multicolumn{10}{|c|}{ Elementos Maiores } \\
\hline $\mathrm{SiO2}$ & 71.64 & 71.92 & 72.94 & 73.01 & 74.34 & 74.5 & 75 & 75.27 & 75.36 & 71.9 \\
\hline TiO2 & 0.43 & 0.48 & 0.21 & 0.08 & 0.08 & 0.05 & 0.06 & 0.03 & 0.09 & 0.31 \\
\hline Al2O3 & 14.67 & 13.18 & 14.54 & 14.19 & 13.82 & 13.8 & 13.6 & 13.45 & 13.78 & 14 \\
\hline $\mathrm{Fe} 2 \mathrm{O3}$ & 0.66 & 0.95 & 0.57 & 0.07 & 0.07 & 0.1 & 0.1 & 0.49 & 0.12 & 0.44 \\
\hline MnO & 0.1 & 0.9 & 0.48 & 0.51 & 0.78 & 0.7 & 0.6 & 0.1 & 0.53 & 1.4 \\
\hline MgO & 0.01 & 0.03 & 0.02 & 0.02 & 0.01 & 0.02 & 0.01 & 0.01 & 0.02 & 0.03 \\
\hline $\mathrm{CaO}$ & 0.05 & 0.69 & 0.02 & 0.07 & 0.04 & 0.1 & 0.05 & 0.05 & 0.04 & 0.36 \\
\hline $\mathrm{Na2O}$ & 0.59 & 1.94 & 0.72 & 1.62 & 1.55 & 0.94 & 1.3 & 1.2 & 1.48 & 1.7 \\
\hline K2O & 2.09 & 2.97 & 2.56 & 3.89 & 3.82 & 3.4 & 3.7 & 3.01 & 3.24 & 3.2 \\
\hline P2O5 & 0.06 & 0.17 & 0.03 & 0.01 & 0.01 & 0.06 & 0 & 0.04 & 0.02 & 0.1 \\
\hline LOI & 0.47 & 1.36 & 0.51 & 0.36 & 0.02 & 1.09 & 0.3 & 0.22 & 0.09 & 0.59 \\
\hline \multirow[t]{2}{*}{ Total } & 100.18 & 99.64 & 99.83 & 99.44 & 99.55 & 100.56 & 99.92 & 99.56 & 100.0 & 99.83 \\
\hline & \multicolumn{10}{|c|}{ Elementos Menores } \\
\hline $\mathbf{R b}$ & 308 & 188 & 290 & 201 & 167 & 230 & 180 & 206 & 189 & 190 \\
\hline $\mathbf{B a}$ & 1516 & 1436 & 1452 & 901 & 831 & 1100 & 900 & 812 & 1010 & 1160 \\
\hline $\mathrm{Sr}$ & 252 & 431 & 264 & 287 & 213 & 280 & 310 & 169 & 356 & 400 \\
\hline $\mathrm{Nb}$ & 3 & 14 & 5 & 5 & 9 & 17 & 8 & 6 & 7 & 9 \\
\hline $\mathbf{Z r}$ & 29 & 308 & 36 & 45 & 38 & 45 & 33 & 69 & 39 & 270 \\
\hline $\mathbf{Y}$ & 7 & 7 & 5 & 10 & 6 & 10 & 9 & 22 & 12 & 7 \\
\hline Hf & 1.1 & 8.2 & 1.5 & 2.2 & 3.1 & 3.2 & 2.6 & 2.4 & 2.9 & 2.5 \\
\hline \multirow[t]{2}{*}{$\mathbf{T a}$} & 0.4 & 0.5 & 0.7 & 0.5 & \begin{tabular}{l|}
0.3 \\
\end{tabular} & 0.5 & 0.3 & 0.5 & 0.5 & 0.4 \\
\hline & \multicolumn{10}{|c|}{ Elementos Terras Raras } \\
\hline $\mathbf{L a}$ & 7.40 & 20.1 & 8.9 & 7.30 & \begin{tabular}{|l|}
8.30 \\
\end{tabular} & \begin{tabular}{|l|}
7.61 \\
\end{tabular} & \begin{tabular}{|l|}
7.96 \\
\end{tabular} & 9.8 & 8.8 & 84.62 \\
\hline $\mathrm{Ce}$ & 13.0 & 35.9 & 12.9 & 14.2 & 16.3 & 16.4 & 15.95 & 21.0 & 17.3 & 172.6 \\
\hline Pr & 1.63 & 4.25 & 1.54 & 1.76 & 1.35 & 2.01 & 1.85 & 2.54 & 2.25 & 19.2 \\
\hline Nd & 6.60 & 15.5 & 9.10 & 6.20 & 6.10 & 6.24 & 5.79 & 8.4 & 10.3 & 57.8 \\
\hline $\mathrm{Sm}$ & 1.60 & 2.70 & 1.50 & 1.00 & 1.00 & 1.14 & 1.07 & 2.00 & 1.20 & 6.35 \\
\hline Eu & 1.04 & 1.31 & 1.65 & 1.43 & 1.36 & 0.8 & 0.66 & 0.93 & 1.02 & 0.8 \\
\hline Gd & 1.50 & 2.00 & 1.30 & 0.80 & 1.10 & 1.04 & 0.99 & 1.40 & 0.90 & 2.99 \\
\hline $\mathbf{T b}$ & 0.20 & 0.30 & 0.20 & 0.20 & 0.20 & 0.16 & 0.15 & 0.20 & 0.20 & 0.42 \\
\hline Dy & 1.20 & 1.30 & 1.30 & 0.50 & 0.80 & 0.53 & 0.55 & 0.90 & 0.60 & 0.83 \\
\hline Ho & 0.20 & 0.20 & 0.30 & 0.20 & 0.10 & 0.10 & 0.12 & 0.20 & 0.10 & 0.14 \\
\hline $\mathbf{E r}$ & 0.60 & 0.70 & 0.60 & 0.40 & 0.40 & 0.28 & 0.31 & 0.08 & 0.30 & 0.38 \\
\hline $\mathbf{T m}$ & 0.08 & 0.1 & 0.07 & 0.02 & 0.02 & 0.04 & 0.03 & 0.08 & 0.03 & 0.06 \\
\hline Yb & 0.50 & 0.60 & 0.30 & 0.30 & 0.30 & 0.33 & 0.28 & 1.70 & 0.30 & 0.34 \\
\hline $\mathbf{L u}$ & 0.07 & 0.11 & 0.05 & 0.08 & 0.05 & 0.07 & 0.07 & 0.12 & 0.06 & 0.06 \\
\hline
\end{tabular}

\section{GEOQUÍMICA: ELEMENTOS MAIORES, MENORES E TRAÇO}

Foram analisadas um total de dez (10) amostras para caracterização geoquímica dos litotipos estudados, sendo que nove (9) delas correspondem a amostras do leucogranito (fácies hololeucocrática) e uma correspondente ao monzogranito (fácies média-homogênea amostra PJT-12 F). A fácies média-homogênea, composta essencialmente por monzogranitos, é considerada como padrão representativo para o Granito Pedra Branca de uma forma geral, por 
se apresentar como a fácies de maior volume e de maior distribuição espacial dentro do plúton (Porto Jr., 2004). Os resultados geoquímicos para elementos maiores, menores e ETR estão representados na tabela 1 .

A análise dos dados permite observar que os teores de $\mathrm{TiO}_{2}$ para os leucogranitos são, de uma forma geral, menores (média de $0,17 \%$ peso) se comparados com os monzogranitos $(0,31 \%$ peso $)$, evidência corroborada pela petrografia, uma vez que minerais acessórios como a titanita e minerais opacos (p.ex.: ilmenita) são encontrados em baixos volumes (ou mesmo estão ausentes) nos leucogranitos.

Comportamento semelhante é detectado na avaliação dos valores obtidos para $\mathrm{P}_{2} \mathrm{O}_{5}$, reafirmando a premissa estabelecida anteriormente, compatível com as baixas quantidades de apatita apresentada pelo leucogranito. Analogamente, os baixos teores de $\mathrm{CaO}$, cerca de 3 vezes menor que na amostra padrão para a faciologia dominante, são explicados pelo frequente aparecimento de plagioclásio de $3^{\mathrm{a}}$ geração de composição albítica nos leucogranitos, que sobrecresce os grãos de plagioclásio de $1^{a}$ geração.

Os elementos $\mathrm{Rb}, \mathrm{Sr}$ e $\mathrm{Zr}$ apresentam valores muito característicos aos leucogranitos, dentre esses elementos, o $\mathrm{Zr}$ destoa consideravelmente quando comparados aos dados apresentados para os monzogranitos. Devido às propriedades geoquímicas conferidas ao $\mathrm{Rb}$, há uma tendência geral deste elemento substituir o potássio $(\mathrm{K}) \mathrm{em}$ feldspatos e alguns argilominerais. Os teores de $\mathrm{Rb}$ para os leucogranitos são, em geral, maiores que para os monzogranitos.

Tal característica está associada ao alto volume de microclina encontrado nessas rochas. Por sua vez, o $\mathrm{Sr}$, comumente substitui o Ca no plagioclásio e, como já descrito, devido às características do plagioclásio de $3^{\mathrm{a}}$ geração, há um relativo empobrecimento em cálcio e consequentemente de estrôncio nos leucogranitos. Baixas concentrações de $\mathrm{Zr}$ (cerca de 4 vezes menor) também deve ser atribuída à ausência de minerais acessórios que concentrem elementos de alto potencial iônico, como por exemplo, o zircão.

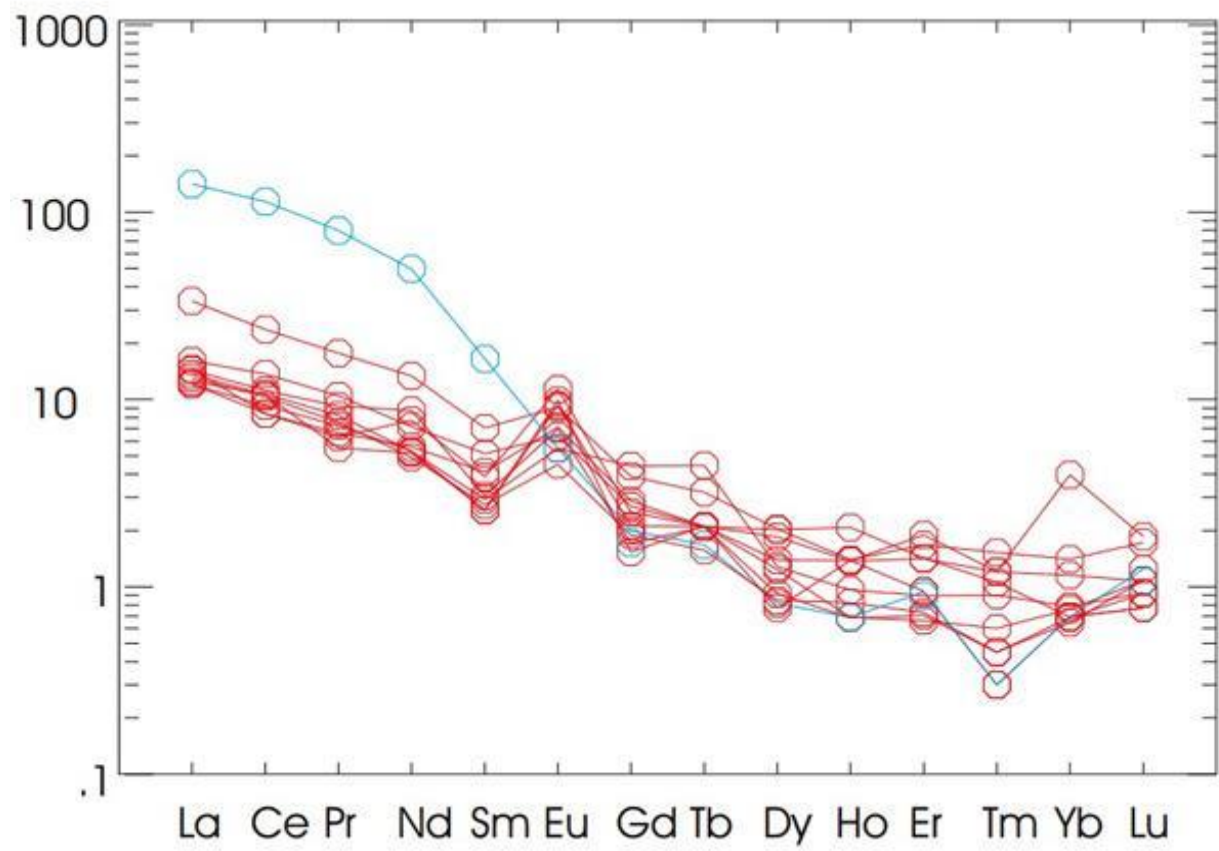

Figura 10 - Diagrama normalizado para ETR (Boynton, 1984) para os leucogranitos (círculos vermelhos) e monzogranito (círculo azul) no Granito Pedra Branca.

Na figura 10 é representado um diagrama de ETR normalizado para o condrito (Boyton, 1984) para as rochas que representam o acamamento magmático. Observa-se que os leucogranitos são fortemente empobrecidos em ETR $_{\mathrm{L}}$ (cerca de dez vezes) em relação ao monzogranito e apresentam valores compará-

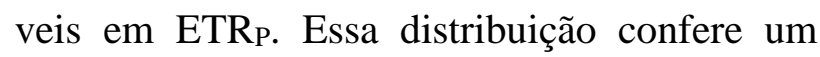
padrão pouco fracionado para os leucogranitos apresentado pelo diagrama normalizado para ETR. Esse comportamento é provavelmente associado à ausência de minerais que concentrem ETR $\mathrm{L}_{\mathrm{L}}$. Devido aos altos valores de coeficiente de partição de $\mathrm{ETR}_{\mathrm{L}}$ em líquidos 
magmáticos silicosos (e.g. Mahood \& Hildreth $\left.(1983), K_{L a}^{A l l a n i t a}=2594,5\right)$, o fracionamento de allanita como fase acessória no monzogranito empobreceu o magma residual em ETR $_{\mathrm{L}}$, que posteriormente ao se cristalizar deu origem aos leucogranitos.

A marcante anomalia positiva para o európio (Eu) apresentada pelos leucogranitos é devido ao comportamento dual desse elemento perante processos de equilíbrio cristal-líquido. $\mathrm{O} \mathrm{Eu}^{+2}$ possui carga menor e raio iônico maior comparativamente com o $\mathrm{Eu}^{+3}$, isso lhe impõe um comportamento semelhante aos íons de
$\mathrm{Sr}^{+2}$, que por vezes substituem os íons de $\mathrm{Ca}^{+2}$ na estrutura aberta do plagioclásio.

De tal modo, as anomalias positivas de Eu, podem estar associadas à acumulação de feldspatos, aliada ao emprobrecimento relativo de fases minerais concentradoras de ETR $_{\mathrm{L}}$, levando ao padrão pouco fracionado desses elementos em diagramas normalizados, como destacado na figura 10 .

As baixas razões $\mathrm{La} / \mathrm{Yb}$ mostram que a evolução dessas rochas caminhava para composições eutéticas, cristalizando uma combinação de álcali-feldspato, plagioclásio e quartzo.

\section{O PROCESSO DE DIFERENCIAÇÃO MAGMÁTICA}

Um modelo de evolução magmática consistente deve testar a cogeneticidade entre as bandas do acamamento magmático, ou seja, entre os monzogranitos e os leucogranitos. A amostra PBG $2\left(71,64 \%\right.$ peso de $\left.\mathrm{SiO}_{2}\right)$ representa o magma menos evoluído dentro da série correspondente aos leucogranitos representando, assim, o possível magma parental dentro da série magmática estudada. A amostra PJT-8 $\left(75,36 \%\right.$ peso de $\left.\mathrm{SiO}_{2}\right)$ representa, de forma análoga, o magma mais evoluído dentro da série. Já a amostra PJT-12F $\left(71,90 \%\right.$ peso de $\left.\mathrm{SiO}_{2}\right)$ é representativa para os monzogranitos.

As variações percentuais das razões entre elementos imóveis, constantemente maiores que $50 \%$, mostraram a impossibilidade da geração exclusivamente por cristalização fracionada dos leucogranitos a partir de um magma parental de composição referente àquela dos monzogranitos (Tabela 2). Com isso, fica favorecida a hipótese de que outros mecanismos evolutivos foram responsáveis por sua diferenciação.

Os dados geoquímicos apresentados na Tabela 2 mostram que a variação percentual entre a amostra que representa o magma parental PBG-2 (71,64\% peso de $\left.\mathrm{SiO}_{2}\right)$ e a amostra que representa o magma mais evoluído PJT-8 $\left(75,36 \%\right.$ peso de $\left.\mathrm{SiO}_{2}\right)$, para as razões adotadas, é constantemente menor que $50 \%$. Assim, é possível assumir que todos os leucogranitos tenham evoluído por um processo único de diferenciação a partir do magma parental de composição dada pela amostra PBG-2 (71,64\% peso de $\left.\mathrm{SiO}_{2}\right)$, que representaria o magma leucogranítico, cabendo ressaltar que os padrões de ETR para as amostras dos leucogranitos são homogêneos, indicando uma cogeneticidade para a sequência.

Tabela 2 - Razões e parâmetros petroquímicos utilizados para o modelo de evolução da fácies hololeucocrática do Granito Pedra Branca. *PJT-12F corresponde ao monzogranito.

\begin{tabular}{c|c|c|c|c|c|c|c|c|c|c}
\hline & $\begin{array}{c}\text { PBG } \\
\mathbf{2}\end{array}$ & $\begin{array}{c}\text { RG } \\
\mathbf{0 5}\end{array}$ & $\begin{array}{c}\text { PIT } \\
\mathbf{0 8}\end{array}$ & $\begin{array}{c}\text { PJT } \\
\mathbf{1 0 C}\end{array}$ & $\begin{array}{c}\text { PJT } \\
\mathbf{5 A}\end{array}$ & $\begin{array}{c}\text { PST } \\
\mathbf{5 A}\end{array}$ & $\begin{array}{c}\text { PJT } \\
\mathbf{1 0}^{\mathbf{a}}\end{array}$ & $\begin{array}{c}\text { PIT } \\
\mathbf{0 3 E}\end{array}$ & $\begin{array}{c}\text { PJT } \\
\mathbf{8}\end{array}$ & $\begin{array}{c}* \text { PJT } \\
\mathbf{1 2} \mathbf{F}\end{array}$ \\
\hline $\mathbf{S i O 2}$ & 71.64 & 71.92 & 72.94 & 73.01 & 74.34 & 74.5 & 75 & 75.27 & 75.36 & 71.9 \\
\hline $\mathbf{L a} / \mathbf{Y b}$ & 13.88 & 29.7 & 23.6 & 25.8 & 5.82 & 31.05 & 23.06 & 28.49 & 32.1 & 249 \\
\hline $\mathbf{Z r} / \mathbf{H f}$ & 25.6 & 37.7 & 24 & 20.5 & 12.3 & 14.1 & 12.7 & 28.3 & 13.4 & 108 \\
\hline $\mathbf{T a} / \mathbf{H f}$ & 0.33 & 0.06 & 0.16 & 0.12 & 0.22 & 0.1 & 0.17 & 0.23 & 0.17 & 0.16 \\
\hline $\mathbf{N b} / \mathbf{Z r}$ & 0.11 & 0.14 & 0.11 & 0.18 & 0.09 & 0.05 & 0.38 & 0.24 & 0.24 & 0.03 \\
\hline $\mathbf{( E u / E u * ) n}$ & 0.449 & 0.396 & 0.499 & 0.432 & 0.385 & 0.498 & 0.598 & 0.477 & 0.567 & 0.965 \\
\hline
\end{tabular}

\section{Modelo Reológico e a Formação do} Acamamento Magmático

Diversos processos têm sido propostos para explicar a origem do acamamento magmático em plútons graníticos, tais como: convecção termoquímica (Mcbirney, 1980b), fluxo magmático nas margens da intrusão (e.g. Naney \& Swanson, 1980) e zonas de cisalhamento associadas a porções em contato com a encaixante (Barriere, 1981). Neste trabalho, propõe-se que a origem do acamamento magmático no Granito Pedra Branca é resultado 
de efeitos combinados de cristalização in situ e percolação de líquido intersticial para zonas de baixo gradiente de pressão pelo processo de filter pressing (Mckenzie, 1987).

A interpretação para a origem do acamamento magmático aqui proposta foi baseada em modelo análogo de magmas silicosos, proposto originalmente por Vigneresse et al. (1996). As interpretações adotadas foram ponderadas exclusivamente por observações petrográficas e geoquímicas. A ausência de estruturas de extração magmática em campo fragiliza o modelo, portanto o modelo deve ser entendido como uma analogia aos experimentos propostos por Vigneresse et al. (1996).

Para explicar o mecanismo de diferenciação proposto, devemos levar em consideração que a transição reológica do magmatismo no Granito Pedra Branca está fortemente ligada ao teor de material cristalizado em que o líquido magmático intersticial, principalmente nas zonas de borda da intrusão, pôde ser "espremido" e remobilizado pelo processo de filter pressing. Os dados petrográficos e geoquímicos nos permitem dividir a história de cristalização magmática, embasado no modelo reológico de Vigneresse et al. (1996), em:

(I) $\mathrm{Em}$ um estágio inicial, com aproximadamente $20 \%$ de cristalização fracionada, os cristais puderam rotacionar livremente, segundo um fluxo magmático, até um intervalo máximo de aproximadamente $55 \%$ de material cristalizado, definindo o limite de percolação rígida - RPT (rigid percolation threshold). Nos contatos com os ortognaisses encaixantes, diferenciação por cristalização in situ, por sua vez, teve papel essencial em formar regiões de baixas velocidades de fluxo magmático, dado a natureza não newtoniana de líquidos graníticos (Best, 2003). Ainda neste intervalo, boa parte dos minerais acessórios, máficos e opacos precoces foram cristalizados, consequentemente empobrecendo o líquido residual em elementos compatíveis e de alto potencial iônico.

(II) Acima do limite de percolação rígida (RPT), até o limite de bloqueio de partículas
PLT (particle locking threshold) de $\sim 72-75 \%$ de material cristalizado, as partículas sólidas se interagiram mecanicamente e o contato entre elas responderam ao stress causado por tensões diapíricas e de ascensão do magma, assim o líquido intersticial foi forçado a fluir para zonas de mais baixos gradientes de pressão. A remoção do líquido intersticial se deu preferencialmente em zonas de borda da intrusão e que foi limitada pela permeabilidade do crystal mush, assim como pelo aumento da componente de cisalhamento nessas regiões. Ortogonal ao tensor de compactação do crystal mush $\left(\sigma_{1}\right)$, regiões de mais baixas pressões $\left(\sigma_{3}\right)$, se formaram, onde o líquido residual de composição muito próxima ao eutético granítico foi forçada a migrar e se cristalizar. Interpretamos que no intervalo entre RPT e PLT, processos cumuláticos relacionados ao fluxo de magma próximo à encaixante combinados com mobilização de líquido intersticial por filter pressing (Mckenzie, 1987) foram responsáveis pela geração dos leucogranitos.

O modelo reológico de magmas graníticos proposto por Vigneresse et al. (1996) se mostrou eficiente para explicar o acamamento magmático encontrado no Granito Pedra Branca. Aliado aos dados geoquímicos e petrográficos, o modelo coincide com importantes intervalos de transição reológica durante o "emplacement" do magma granítico. Devemos destacar também que o modelo petrogenético mostrou a impossibilidade da geração dos leucogranitos exclusivamente por cristalização fracionada a partir de um magma parental de composição monzogranítica, reforçando o modelo reológico e de diferenciação magmática proposto.

Outras variáveis devem ser consideradas para o entendimento completo do modelo, como por exemplo, a presença de veios leucograníticos que cortam todas as fácies do Granito Pedra Branca. Adicionado ao modelo reológico, essa observação de campo pode ter sido resultado do escape do material filtrado por filter pressing para as rochas encaixantes, que incluem em boa parte todas as faciologias do Granito Pedra Branca (Porto Jr. 1993a).

\section{CONCLUSÕES}

O acamamento magmático no Granito Pedra Branca foi gerado por diferenciação por processo de cristalização in situ e posteriormente por filter pressing de um magma granítico com composição muito próxima ao ponto eutético. Até o limite de 
percolação rígida (RPT), com aproximadamente $55 \%$ de material cristalizado, cristalização in situ induzida por fluxo magmático próximo à borda do conduto foi o principal mecanismo de diferenciação magmática para o acamamento magmático.

Zonas de enclaves deformados, bem como foliação críptica junto a regiões próximas ao contato com os ortognaisses encaixantes, indicam que tensões diapíricas e tensões póscolisionais formaram o cenário compressivo necessário para se sustentar o modelo. Entre o limite de percolação rígida (RPT) até o limite de bloqueio de partículas (PLT), correspondendo o intervalo entre $55 \%$ a 72 $75 \%$ de material cristalizado, o magma diferenciado por cristalização in situ passa a responder reologicamente ao um líquido muito viscoso, compreendendo ao crystal mush.
O aumento gradual do atrito interno das partículas em direção às encaixantes levou à compactação desse magma, mobilizando o líquido magmático intersticial para regiões de mais baixos gradientes de pressão.

O estado reológico compreendido entre RPT e PLT é aqui considerado como dominado pelo processo de diferenciação por filter pressing.

Conclui-se ainda que os monzogranitos intercalados no acamamento magmático correspondem ao resíduo diferenciado por filter pressing e os leucogranitos representam, de forma análoga, ao líquido segregado por esse processo. Analogamente os monzogranitos da fácies média-homogênea, dominante nas partes centrais do plúton, representam porções indiferenciadas por estes processos, sendo predominantemente gerados por cristalização fracionada (Porto Jr. 2004).

\section{REFERÊNCIAS}

ALMEIDA, F.F.M.; AMARAL, G.; CORDANI, U.G.; KWASHITA, K. The Precambrian evolution of the South America cratonic margin south of Amazon River. In: NAIRN, A.E.M.; STEHLI, F.G.; UYEDA, S. (Eds), Ocean basins and margins. N. York, Plenum. v. 1, p. 411-446. 1973.

BARRIÈRE, M. On curved laminae, graded layers, convection currents and dynamic crystal sorting in the Ploumanac'h (Brittany) subalkaline granite: Contributions to Mineralogy and Petrology, n. 77, p. 214-224, 1981

BEST, M.G. Igneous and metamorphic petrology, 2nd ed. Blackwell Publishing Company. 729p

BOYNTON, W.V. Geochemistry of rare earth elements: meteorite studies. In: HENDERSON P. (ed.), Rare earth element geochemistry. Elsevier, p. 63-144. 1984.

HASUI, Y. \& OLIVEIRA, M.A.F. Província Mantiqueira. Setor Central. In: ALMEIDA, FFM \& HASUI, Y. O PréCambriano do Brasil. Ed. Edgard Blucher. p. 308-344. São Paulo. 1984.

HEILBRON, M. \& MACHADO, N. Timing of terrane accretion in the Neoproterozoic-Eopaleozoic Ribeira orogen (SE Brasil). Precambrian Research, v. 125, p. 87-112, 2003.

HEILBRON, M. O Segmento Central da Faixa Ribeira: Síntese Geológica e Ensaio de Evolução Geotectônica. Rio de Janeiro, 1995(a). 92p. Tese (Livre Docência), Universidade do Estado do Rio de Janeiro.

HEILBRON, M., VALERIANO, C.M., VALLADARES, C.S.; MACHADO, N. A orogênese Brasiliana no segmento central da Faixa Ribeira, Brasil. Revista Brasileira de Geociências, v. 25, n. 4, p. 245-266, 1995.

MAHOOD, G. \& HILDRETH, W. Large partition coefficients for trace elements in high-silica rhyolites. Geochemist Cosmochim Acta, v. 47, p. 11-30, 1983.

MCBIRNEY, A.R. Differentiation of the Skaergaard Intrusion. Nature, v. 253, p. 691-694, 1975.

MCBIRNEY, A. R. Mixing and Unmixing of magmas. Journal Volcanology Geothermal Res, v.7, p. 357-371, 1980.

MCKENZIE, D.P. The compaction of igneous and sedimentary rocks. Geol. Soc. London, v. 144, p. 299-307, 1987.

NANEY, M.T. \& SWANSON, S.E. The effect of Fe and Mg on crystallization in granitic systems: American Mineralogist, v. 65, p. 639-653. 1980.

PANKHUST, R.J. Isotope and trace element evidence for the origin and evolution of Caledonian granites in the Southern Highlands. In: ATHERTON, M. P \& TARNEY (eds.): Origen of Granite Batholiths: Geochemical Evidence. Shiva Publ. Ltda, p. 18-33. 1979.

PENHA, H.M. \& WIEDEMANN, C.M. Granitóides da região central do Rio de Janeiro. In: CONGRESSO BRASILEIRO GEOLOGIA, 33, Rio de Janeiro, 1984. Roteiro de Excursões, p. 5433-5455.

PENHA, H.M. Geologia do Maciço da Pedra Branca, Rio de Janeiro, RJ. Anais da Academia Brasileira de Ciências, v. 53, n. 3, p. 355, 1984

PITCHER, W.S. Granites and Yet More Granites Forty Years on. Geologische Rundschau Geol Rundsch, v. 76, n. 1, p. 51-79. 1987(b)

PITCHER, W.S. Granite type and tectonic environment. In: HSU, K. (Ed.) Mountain Processes. Acad. Press. London. p. 19-40, 1982.

PONS, J.; BARBEY, P.; NACHIT, H.; BURG, J.P. "Development of Igneous Layering during Growth of Pluton: The Tarçouate Laccolith (Morocco)." Tectonophysics, v. 413, n. 3-4, p. 271-86, 2006.

PORTO JR, R. \&VALENTE, S.V. As rochas granitoides do norte da Serra da Pedra Branca e suas relações com as encaixantes gnáissicas na região de Bangu, Rio de Janeiro, RJ. In: CONGRESSO BRASILEIRO DE GEOLOGIA, 35, 1988, Belém. Anais...Belém: SBG, 1988, v. 3, p. 1066-1079.

PORTO JR. R. Petrologia das Rochas Graníticas das Serras de Pedra Branca e Misericórdia, Município do Rio de Janeiro, RJ, Brasil. Rio de Janeiro, 1993, 222p. Dissertação (Mestrado), Universidade Federal do Rio de Janeiro.

PORTO JR.R. Inclusões em Megacristais de Microclina em Granitos. Complexo Granítico Pedra Branca, Rio de Janeiro, RJ, Brasil. Revista Universidade Rural. Série Ciências Exatas e da Terra, Rio de Janeiro, v. 21, n. 01, p. 37-48. 2002.

PORTO JR, R. Petrogênese das Rochas do Maciço da Pedra Branca. Rio de Janeiro, RJ. Rio de Janeiro, 2004. 283p. Tese (Doutorado), Universidade Federal do Rio de Janeiro.

SCHMITT, R.S. Orogenia Búzios - Um evento tectonometamórfico cambro-ordoviciano caracterizado no Domínio Tectônico de Cabo Frio, Faixa Ribeira - sudeste do Brasil. Rio de Janeiro. 2001. 273p. Tese (Doutorado), 
Instituto de Geologia, Universidade Estadual do Rio de Janeiro.

SILVA, L.C., SANTOS, R.A., DELGADO, I.M., CUNHA, H.C.S. Mapa Geológico do estado do Rio de Janeiro, escala 1:500.000. CPRM, MME. Rio de Janeiro, 2000.

TUPINAMBÁ, M.; TEIXEIRA, W.; HEILBRON, M.; BASEI, $M$. The Pan-African/Brasiliano arc-related magmatism at the Costeiro Domain at the Ribeira Belt, southeastern Brazil. In: INTERNATIONAL CONFERENCE ON BASEMENT TECTONICS, Ouro Preto, 1998. Anais...Ouro Preto: 1998, p. 12-14.

TAIT, S. \& JAUPART, C. Physical processes in the evolution of magmas. In: NICHOLS, J. \& RUSSELL J.K. (eds.), Modern Methods of Igneous Petrology: Understanding Magmatic Processes. Reviews in Mineralogy and Geochemistry, v. 24, n. 1, p. 125-152, Mineralogical Society of America, p. 1990.

VANCE, J.A. On syneusis. Contributions to Mineralogy and Petrology, v. 24, p. 7-29, 1969.
VERNON, R.H. A pratical guide to rock microestruture. Cambridge: Cambridge University Press, 594p., 2003.

VIGNERESSE, J.L.; BARBEY, P. \& CUNEY, N. Rheological Transitions During Partial Melting and Crystallization with Application to Felsic Magma Segregation and Transfer. Journal of Petrology, v. 37, p. 1579-1600, 1996.

WAGER, L.R.; BROWN, G.M.; WADSWORTH, M.J. Types of igneous cumulates. Journal of Petrology, v. 1, p. 73-85, 1960.

WEINBERG, R.F.; SIAL, A.N.; PESSOA, R.R. Magma Flow within the Tavares Pluton, Northeastern Brazil: Compositional and Thermal Convection. Geological Society of America Bulletin, v. 113, n. 4, p. 508-520, 2001.

Submetido em 04 de março de 2017 Aceito em 21 de fevereiro de 2018 